\title{
Differential sensitivity of ovarian follicles to gonadotrophin stimulation in broiler and layer lines of domestic fowl
}

\author{
P. M. Hocking and H. A. McCormack \\ Roslin Institute (Edinburgh), Roslin, Midlothian, EH25 9PS, UK
}

\begin{abstract}
Differences in the reproductive potential of female broiler parent and layer fowl are related to differences in the recruitment of follicles to the preovulatory hierarchy. Broiler and laying hens were fed ad libitum or a restricted diet during rearing and ad libitum after sexual maturity. The sensitivity of thecal tissue, from ovarian follicles of different sizes, from layer and broiler fowl to stimulation by pregnant mares' serum gonadotrophin (PMSG) was determined to test the hypothesis that differences in egg production are associated with changes in the sensitivity of ovarian follicles to stimulation by gonadotrophin. The activity of ornithine decarboxylase $0.5-4 \mathrm{~h}$ after injection of $200 \mathrm{iu}$ PMSG $\mathrm{kg}^{-1}$ body mass was assessed in thecal tissue from small white follicles $2-3$ and 5-6 $\mathrm{mm}$ in diameter and in the smallest preovulatory yellow follicle. Basal activity was similar in layers and broiler breeders. PMSG-stimulated ornithine decarboxylase activity in follicles of 5-6 mm diameter was greater in broiler breeders than in layers. There was no difference between the lines in PMSG-stimulated ornithine decarboxylase activity in follicles of 2-3 mm diameter or in small yellow follicles. It was concluded that the low egg production and high prevalence of eggs with defective shells in broiler parents compared with layers may be related to the increased sensitivity of follicles to endogenous gonadotrophins at the critical stage of recruitment to the preovulatory hierarchy.
\end{abstract}

\section{Introduction}

The ovary of a laying hen contains a hierarchy of 5-7 large yellow follicles greater than $8 \mathrm{~mm}$ in diameter. This allows a mature follicle to ovulate on successive days for extended periods (Etches, 1990). In contrast to laying hens, the ovaries of broiler parent hens contain about twice as many yellow follicles, and egg production is relatively poor (Hocking et al., 1987). The ovulation of two or more ova on one day results in soft, thin or poorly shelled and double-yolked eggs; a high incidence of internal ovulation also occurs (Hocking et al., 1987; Hocking, 1993). This phenomenon persists throughout lay and is a major reason for the relatively poor performance of broiler parent birds (broiler breeders) fed ad libitum. Production of hatching eggs in commercial flocks of broiler breeder hens is enhanced by severely limiting body mass during rearing as the number of developing yellow follicles during the laying period is decreased (Hocking et al., 1987; Katanbaf et al., 1989). Similar changes have been observed in turkeys and ducks selected for rapid growth (Hocking, 1990, 1992), although, commercially, food restriction in these species is not as severe as in broiler parent flocks.

The reasons for the recruitment of additional yellow follicles to the hierarchy are not known and the present work was undertaken to determine whether follicular tissue from broiler breeders was more sensitive to gonadotrophin stimulation than is tissue from the ovaries of layers. Any increased sensitivity to pituitary hormones could form the basis for the increased rate

Received 30 January 1995. of recruitment of follicles into the hierarchy of yellow follicles that eventually ovulate.

Injection of pregnant mares' serum gonadotrophin (PMSG) i.v. in vivo increases the number of yellow follicles in the ovaries of hens (Johnson et al., 1985). Armstrong (1986a, b, 1987, 1994) used the activity of the enzyme ornithine decarboxylase, induced by PMSG injection, to monitor differences in the sensitivity of ovarian tissue from follicles of different sizes. Ornithine decarboxylase catalyses the ratelimiting step in the synthesis of polyamines that are essential for cell growth and differentiation (Auvinen et al., 1992). Ornithine decarboxylase, the activity of which increases rapidly in response to hormones, growth factors and tumour promoters (Pegg and McCann, 1982), has been extensively used as a marker of gonadotrophin sensitivity in studies of folliculogenesis in domestic fowl (Armstrong, 1986a, b, 1987, 1994).

A PMSG dose-response experiment was conducted using broiler breeder hens that had been restricted to commercial standards during rearing (body mass was approximately 0.4 of that when fed ad libitum) (Hocking, 1993). In the main experiment, the response to an optimum dose of PMSG over time was determined in tissues from three different sizes of follicle from layers fed ad libitum and from broiler breeder females in which feeding had been restricted during rearing but were fed ad libitum after laying their first egg. In addition, the numbers of normal and defectively shelled eggs from layers and broiler breeders fed ad libitum or restricted during rearing were determined. 


\section{Materials and Methods}

\section{Animals}

One hundred and fifty I-day-old chicks (Gallus domesticus) of a line of broiler parent stock (Ross 1; Ross Breeders Ltd, Newbridge, Midlothian) and 150 1-day-old chicks of a brownegg layer (Hisex; Ross Poultry Ltd, Inverurie, Aberdeen) were housed in 24 pens with a floor area of $3.6 \mathrm{~m}^{2}$ in a randomized block design. Each pen was littered with wood shavings and contained a suspended bell drinker and a tubular feeder. At 18 weeks of age, the birds were transferred to a module of 12 cages measuring $610 \mathrm{~mm} \times 457 \mathrm{~mm}$ (broilers) or $305 \mathrm{~mm} \times$ $457 \mathrm{~mm}$ (layers). Conventional house temperatures of $18-20^{\circ} \mathrm{C}$ were maintained by controlled ventilation and supplementary heating. The daily photoperiod was decreased from $23 \mathrm{~h}$ light: $1 \mathrm{~h}$ dark at 1-day-old to $8 \mathrm{~h}$ light: $16 \mathrm{~h}$ dark $(07.30$ to $15.30 \mathrm{~h}$ ) at 10 days of age. The photoperiod was increased to $14 \mathrm{~h}$ light:10 h dark at 18 weeks, when the birds were caged.

Conventional diets were fed from $0-6$ weeks (11.5 MJ metabolizable energy (ME) $\mathrm{kg}^{-1} ; 180 \mathrm{~g}$ crude protein $(\mathrm{CP})$ $\mathrm{kg}^{-1}$ ) 7-18 weeks (11.5 MJ ME kg-1; $150 \mathrm{~g} \mathrm{CP} \mathrm{kg}^{-1}$ ) and from 19 weeks (11.5 MJ ME kg-1; $160 \mathrm{~g} \mathrm{CP} \mathrm{kg}^{-1}$ ). Birds on restricted diets were allocated, daily at $07.30 \mathrm{~h}$, a quantity of food that was calculated to allow them to achieve a body mass 0.4 of that of birds of the same strain fed ad libitum. Food allocation was increased weekly after caging from 50 and $90 \mathrm{~g}$ day $^{-1}$, respectively, for restricted layers and broiler breeders to 90 and $115 \mathrm{~g}^{\text {day }}{ }^{-1}$ at 22 weeks of age. Layers were fed ad libitum from 23 weeks of age, and broiler breeders were fed ad libitum after they had laid an egg.

\section{Chemicals}

$\mathrm{L}-\left[{ }^{14} \mathrm{C}\right]$ ornithine hydrochloride solution (Amersham International PLC, Bucks) was stored at $4^{\circ} \mathrm{C}$ in ethanol at a specific activity of $2.04 \mathrm{GBq} \mathrm{nmol}^{-1}$. D,L- $\alpha$-Difluoromethylornithine was a gift from Merril Dow Research (Strasbourg). All other chemicals were obtained from Sigma Chemical Co. Ltd (Poole, Dorset) and were of Analar grade. PMSG (Intervet UK Ltd, Cambridge) was diluted with saline supplied with the preparation to the required concentrations.

\section{Observations}

Mean body masses per pen were monitored weekly during rearing so that food allowances could be adjusted to maintain the target body mass gains of restricted birds. Individual body masses were recorded at housing. Egg-laying records were obtained daily for every bird and the shell of each egg was classified as being normal, cracked or soft (non-calcified). Sexual maturity was defined as the age at first oviposition.

\section{Dose-response and stimulation experiments}

A dose-response experiment was conducted at 35 weeks of age on 24 broiler parent stock of an unrelated line maintained on a restricted diet at the Institute. The birds were reared in a similar way to those in the main experiment. Two birds were injected into a wing vein between 11.00 and $12.00 \mathrm{~h}$ with 0 , 100, 200 or 400 iu PMSG kg ${ }^{-1}$ body mass and the experiment was repeated on two successive days. The birds were killed $3 \mathrm{~h}$ after injection (Armstrong, 1987).

The main experiment was conducted with 64 birds, 32 layers fed ad libitum and 32 broiler breeders restricted during rearing and fed ad libitum after the onset of lay. Birds were obtained from different blocks on each day and were 40-50 weeks old. They were injected, between 11.00 and $12.00 \mathrm{~h}$, with $0.2 \mathrm{ml}$ saline $\mathrm{kg}^{-1}$ body mass or 200 iu PMSG $\mathrm{kg}^{-1}$ body mass in the same volume of saline. On each of 2 days, eight birds, and on the third day, 16 birds, from both strains were selected. On the first two days, one bird from each strain and treatment was killed $1,2,3$, and $4 \mathrm{~h}$ after the injection. On the third day, 32 birds in total (two treated and two control of each line) were killed $0.5,1.5,2.5$ and $4 \mathrm{~h}$ after injection. The ornithine decarboxylase assays from these birds were performed at a later date on tissues stored at $-20^{\circ} \mathrm{C}$. The exact time from injection to autopsy was noted for all birds.

The birds were killed in pairs, one control and one PMSGstimulated bird, after the predetermined time, by an overdose of sodium pentobarbitone (Euthatol, Vet Drug Co., Falkirk). The body cavity was opened and the ovaries were exposed. The large (greater than $8 \mathrm{~mm}$ ) yellow follicles were removed and subsequently weighed and counted. The residual ovary was detached and rinsed in ice-cold saline. Small (less than $8 \mathrm{~mm}$ diameter) white follicles were removed to obtain three follicles $2-3 \mathrm{~mm}$ and three follicles $5-6 \mathrm{~mm}$ in diameter. The smallest yellow follicle (about $8-10 \mathrm{~mm}$ diameter) in this experiment and each of the white follicles were slit with a scalpel blade and the yolk and adhering granulosa tissue were squeezed out. The remaining thecal tissue from each of the two classes of white follicle and the yellow follicle were added to $2 \mathrm{ml}$ Tris buffer $\left(50 \mathrm{mmol} \mathrm{l}^{-1} ; \mathrm{pH} 8.2\right.$ at $2^{\circ} \mathrm{C}$ ) and kept on ice. After tissue from each pair of birds had been obtained, the samples were transferred to the laboratory and were immediately homogenized for $10 \mathrm{~s}$ using a Polytron. The tubes were centrifuged at $600 \mathrm{~g}$ for $10 \mathrm{~min}$ at $0-2^{\circ} \mathrm{C}$ and $100 \mu \mathrm{l}$ of the supernatant was pipetted into $100 \mu \mathrm{l}$ of $0.3 \mathrm{mmol}$ pyridoxal phosphate $1^{-1}$ for the ornithine decarboxylase assay (see below). The remaining tissue was frozen $\left(-20^{\circ} \mathrm{C}\right)$ for later determination of protein content by the method of Bradford (1976) using BSA as the protein standard.

\section{Enzyme assay}

The activity of ornithine decarboxylase (EC 4.1.1.17) was measured as described by Armstrong (1986a). Briefly, the sample tubes were incubated with $100 \mu \mathrm{l}\left[{ }^{14} \mathrm{C}\right]$ ornithine hydrochloride solution $(1.8 \mathrm{~Bq})$ at a specific activity of $2.04 \mathrm{GBq}$ $\mathrm{nmol}^{-1}$ in a shaking water bath at $37^{\circ} \mathrm{C}$. The reaction was stopped after $60 \mathrm{~min}$ by injecting $100 \mu \mathrm{l}$ sulphuric acid $\left(5.0 \mathrm{mmol} \mathrm{l}^{-1}\right)$. The incubation was continued for a further $60 \mathrm{~min}$ and the ${ }^{14} \mathrm{CO}_{2}$ released was trapped in filter paper inserts soaked in methylbenzethonium hydroxide (Sigma). The filter paper inserts were then removed and placed in scintillation vials with $4.5 \mathrm{ml}$ Optiphase Hisafe 3 (FSA Laboratories, Loughborough). Radioactivity was counted in a Wallace 1410 liquid scintillation counter (Wallace Oy, Finland). All 
determinations were completed in triplicate and tissue blanks containing BSA $(0.1 \% \mathrm{w} / \mathrm{v})$ and total blanks containing $\mathrm{D}, \mathrm{L}-\alpha-$ difluromethylornithine $\left(5 \mu \mathrm{mol} \mathrm{l}^{-1}\right)$, an irreversible inhibitor of ornithine decarboxylase (Metcalf et al., 1978), were included. The intra-assay coefficient of variation was $10 \%$ and interassay effects were removed by analysis of an appropriate statistical model.

\section{Statistical analyses}

Production data were recorded in a randomized block experiment. Plot means for total production to 45 weeks of age were analysed by conventional analyses of variance. Production of eggs with normal shells was analysed as the rate of production (number of eggs per hen per day from first egg) because some birds were removed for the stimulation experiment. The number of cracked and soft-shelled eggs was expressed as a proportion of the number of eggs with normal shells.

Ornithine decarboxylase activity and the protein content of follicles were transformed to natural logarithms before analysis to normalize the residual errors. The response experiment was analysed by conventional regression analysis of a split-plot model. The model included effects for day, bird, follicle size and linear and quadratic effects for dose of PMSG. Some birds did not have follicles of a particular size and the stimulation data were analysed using a split-plot model by the GENSTAT implementation of the restricted maximum likelihood procedure (National Algorithms Group, 1993). The model included effects for strain, treatment, follicle size and their interactions as fixed effects, and day and bird as random effects. Terms for the linear and quadratic effects of time from injection were included in the model.

\section{Results}

\section{Body masses and egg production}

The mean body masses at 18 weeks of age of the broiler breeders fed ad libitum and on a restricted diet averaged 3.93 and $1.74 \mathrm{~kg}$, respectively; the corresponding values for layers fed ad libitum or restricted were 1.54 and $0.81 \mathrm{~kg}$. Data on the production of normal, cracked and soft-shelled eggs by hens in the four treatment groups are presented (Fig. 1). There was little difference between the two groups of layers but the broilers fed ad libitum produced eggs with normal shells at a significantly lower, and eggs with defective shells at a higher, rate than broilers that had been on a restricted diet during rearing. Age at sexual maturity and average production to 45 weeks of age are presented (Table 1).

\section{Dose-response experiment}

The results of the dose-response experiment are presented (Fig. 2). There was more ornithine decarboxylase activity $(P<0.001)$ in the smaller white follicles compared with the larger white follicles. The means (back transformed) were 4.37 (79) and 4.00 (55), SED 0.12, ln pmol $\mathrm{CO}_{2} \mathrm{~h}^{-1} \mathrm{mg}^{-1}$ protein
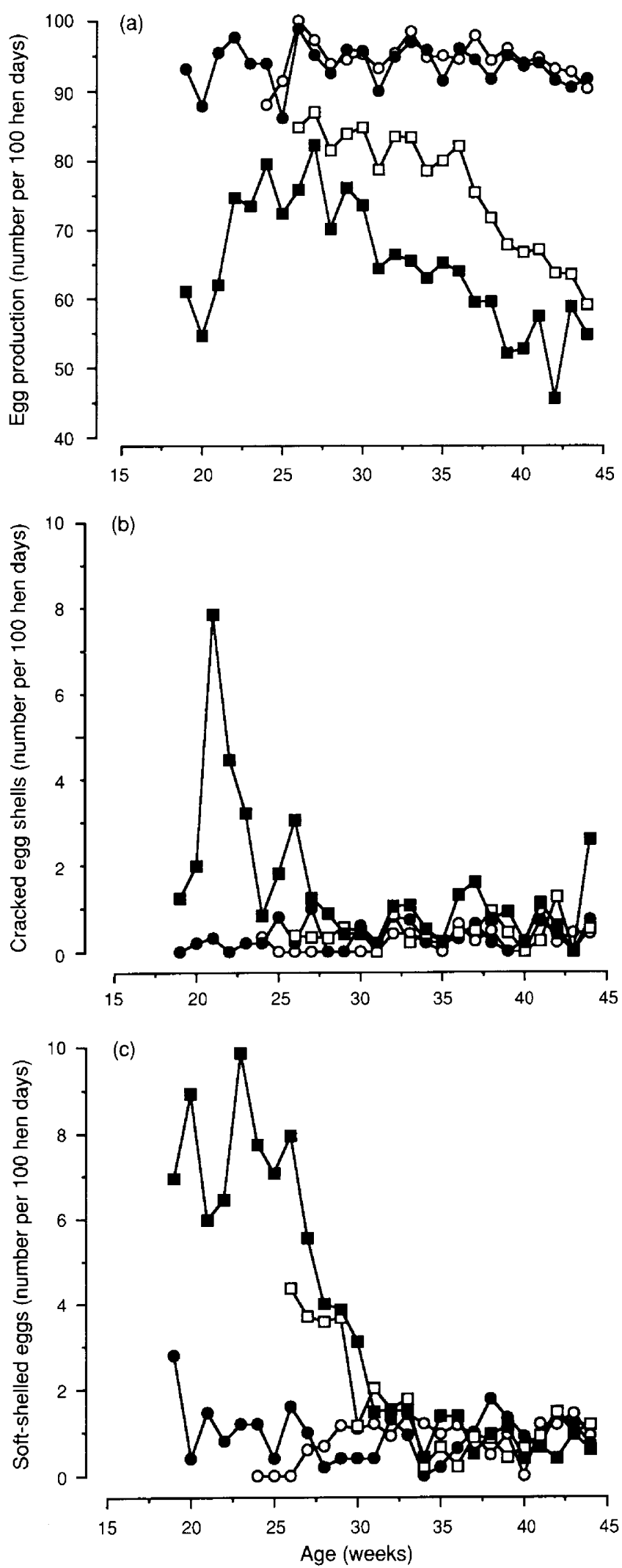

Fig. 1. Rate of production of eggs with (a) normal, (b) cracked or (c) soft shells from the onset of lay to 45 weeks of age in layer and broiler parent stock fed ad libitum or fed a restricted diet during rearing.

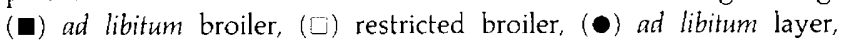
(O) restricted layer.

Downloaded from Bioscientifica.com at 04/26/2023 ๑9:20:07AM 
Table 1. Sexual maturity and reproductive performance up to 45 weeks of age in two strains of fowl fed ad libitum or on a restricted diet during rearing and fed ad libitum after the onset of lay

\begin{tabular}{|c|c|c|c|c|c|}
\hline Strain & Rearing & $\begin{array}{l}\text { Age first } \\
\text { egg laid } \\
\text { (days) }\end{array}$ & Eggs $^{a}$ & $\begin{array}{l}\text { Proportion of eggs } \\
\text { with cracked shells } \\
\left(\times 10^{-3}\right)\end{array}$ & $\begin{array}{l}\text { Proportion of eggs } \\
\text { with soft shells } \\
\left(\times 10^{-3}\right)\end{array}$ \\
\hline \multirow[t]{2}{*}{ Broiler } & Ad libitum & 146 & 0.66 & 22.8 & 52.8 \\
\hline & Restricted & 187 & 0.75 & 6.4 & 20.5 \\
\hline \multirow[t]{2}{*}{ Layers } & Ad libitum & 144 & 0.93 & 2.7 & 9.1 \\
\hline & Restricted & 170 & 0.94 & 2.7 & 9.1 \\
\hline SED & & 2 & 0.01 & 3.6 & 6.2 \\
\hline \multicolumn{6}{|c|}{ Significance of effects } \\
\hline \multicolumn{2}{|c|}{ Strain } & $* * *$ & $* * *$ & $* * *$ & $* * *$ \\
\hline \multicolumn{2}{|c|}{ Rearing } & $* * *$ & $* * *$ & $* *$ & $* *$ \\
\hline \multicolumn{2}{|c|}{ Strain $\times$ rearing } & $* * *$ & $* *$ & $* *$ & $* *$ \\
\hline
\end{tabular}

${ }^{\mathrm{a}}$ Number of eggs (ovipositions) per 100 hen days.

${ }^{b}$ Number of cracked and soft-shelled eggs as a proportion of eggs laid.

${ }^{* *} P<0.01 ;{ }^{* *} P<0.001$.

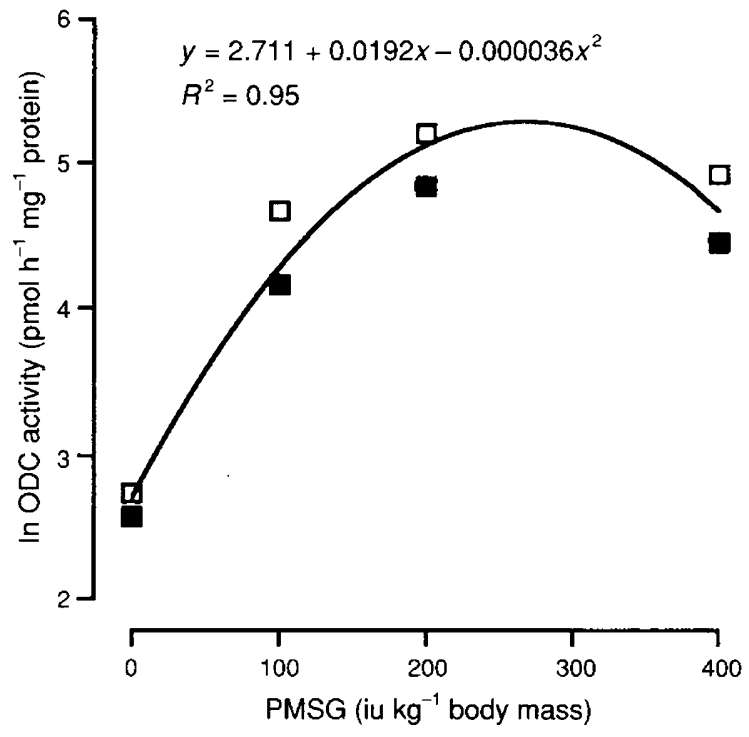

Fig. 2. The activity of ornithine decarboxylase (ODC) in thecal tissue from small white follicles of two sizes from ovaries of broiler parents $3 \mathrm{~h}$ after i.v. injection with different doses of pregnant mares' serum gonadotrophin (PMSG). ( $\square$ ) Follicles $2-3 \mathrm{~mm}$ diameter, ( $\mathbf{\square}$ ) follicles 5-6 mm diameter. The injection volume was $0.2 \mathrm{ml} \mathrm{kg}^{-1}$ body mass.

There was a significant $(P<0.001)$ quadratic response of ornithine decarboxylase activity to dose of PMSG. The responses were similar (parallel) in $2-3 \mathrm{~mm}$ and $5-6 \mathrm{~mm}$ follicles and a single response curve is presented (Fig. 2). On the basis of these results, 200 iu PMSG $\mathrm{kg}^{-1}$ body mass was selected as the dose for the stimulation experiment.

\section{Stimulation experiment}

The results from the first 2 days of the stimulation experiment showed a peak $1 \mathrm{~h}$ after injection and consequently the range of times from injection to autopsy were increased on day 3. In a supplementary experiment, tissue from day 1 was stored

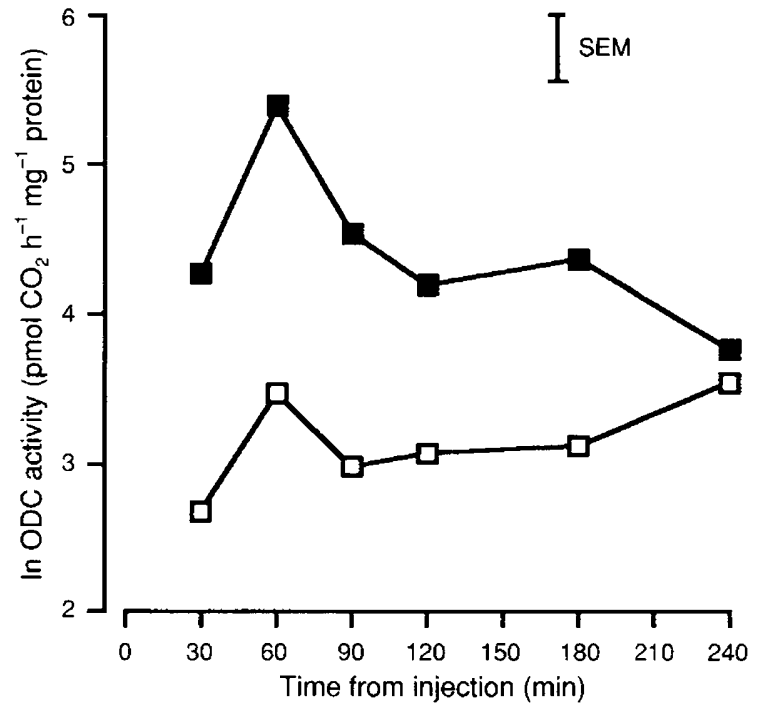

Fig. 3. Mean activity of ornithine decarboxylase (ODC) with time after intravenous injection of saline or pregnant mares' serum gonadotrophin (PMSG). ( $\square$ ) 200 iu PMSG kg ${ }^{-1}$ body mass. ( $\square$ ) control (saline) injection. The injection volume was $0.2 \mathrm{ml} \mathrm{kg}^{-1}$ body mass.

at $-20^{\circ} \mathrm{C}$ and showed similar ornithine decarboxylase activity after 24 and $48 \mathrm{~h}$. Means were 4.765 (117), 4.765 (117) and 4.68I (108), SED 0.096 , In pmol CO $\mathrm{C}^{-1}$ respectively for fresh, 24 and $48 \mathrm{~h}$ storage and all material from day 3 was frozen for subsequent analysis.

There were no significant interactions of time after injection with the main effects of strain, treatment or follicle size in the large data set from 64 birds. There was a curvilinear effect $(P<0.05)$ of time from injection on ornithine decarboxylase activity which was greatest $60 \mathrm{~min}$ after injection in control and PMSG-stimulated birds (Fig. 3). The effect of time after injection on ornithine decarboxylase activity per follicle was similar to that for activity expressed as a proportion of the protein content of the sample and the results are not presented. 
Table 2. Mean activity of ornithine decarboxylase in follicles of different diameter from broiler and layer chickens $(n=32)$ after i.v. injection of $0.2 \mathrm{ml}$ saline $\mathrm{kg}^{-1}$ body mass (control) or 200 iu pregnant mares' serum gonadotrophin (PMSG)

\begin{tabular}{|c|c|c|c|c|c|}
\hline \multirow{2}{*}{$\begin{array}{c}\text { Follicle } \\
\text { size } \\
(\mathrm{mm})\end{array}$} & \multirow[b]{2}{*}{ Strain } & \multicolumn{4}{|c|}{ Ornithine decarboxylase activity } \\
\hline & & \multicolumn{2}{|c|}{ (pmol $\mathrm{CO}_{2} \mathrm{~h}^{-1}$ per folliche) } & \multicolumn{2}{|c|}{$\begin{array}{l}\text { (pmol } \mathrm{CO}_{2} \mathrm{~h}^{-1} \mathrm{mg}^{-1} \text { protein) } \\
\text { Control }\end{array}$} \\
\hline \multirow[t]{2}{*}{$2-3$} & Broiler & 2.749 (16) & $4.144 \quad(63)$ & $3.468(32)$ & $4.575 \quad(97)$ \\
\hline & Layer & $2.316 \quad(10)$ & $3.909 \quad(50)$ & $3.160(24)$ & $4.361 \quad(78)$ \\
\hline \multirow[t]{2}{*}{$5-6$} & Broiler & 3.522 & $5.746(313)$ & $2.548(13)$ & $4.825(125)$ \\
\hline & Layer & $3.548 \quad(35)$ & $5.188(179)$ & $2.798(16)$ & $4.029 \quad(56)$ \\
\hline \multirow[t]{2}{*}{ 8-10 (Yellow) } & Broiler & $4.949(141)$ & $5.819(337)$ & $3.174(24)$ & $3.947 \quad(52)$ \\
\hline & Layer & $5.012(150)$ & $5.652(285)$ & $3.480(32)$ & $3.818 \quad(46)$ \\
\hline Average SED & & \multicolumn{2}{|c|}{0.323} & \multicolumn{2}{|c|}{0.298} \\
\hline
\end{tabular}

Results are presented as natural logarithms and back transformed values are in parentheses.

There was a significant $(P<0.05)$ interaction of strain, follicle size and treatment on ornithine decarboxylase activity $\mathrm{mg}^{-1}$ protein and of treatment by follicle size for ornithine decarboxylase activity per follicle $(P<0.001)$. The basal activity increased with size of follicle, but correction for protein content largely removed these differences (Table 2). Basal ornithine decarboxylase activity of follicles of all three sizes from the two strains were similar. PMSG-stimulated activity $\mathrm{mg}^{-1}$ protein in follicles of $5-6 \mathrm{~mm}$ diameter was 9.5 times the basal value in broiler breeders compared with 3.5 times in layers. In contrast, the increase in follicles of $2-3 \mathrm{~mm}$ diameter and small yellow follicles was similar in both lines (respectively about three and two times). None of the interactions for effects and covariates was significant for protein content. Follicle means (back-transformed) were $-0.600(0.6), 0.926(2.5)$ and 1.731 (5.6), SED 0.113, ln mg protein per follicle $(P<0.001)$. The respective means for layers and broiler breeders were 0.635 (1.9) and 0.736 (2.1), SED 0.085, ln mg protein per follicle (not significant) and $0.582(1.8)$ and $0.790(2.2)$, SED 0.084, ln $\mathrm{mg}$ protein per follicle for control and PMSG-injected birds $(P<0.05)$.

\section{Discussion}

The feeding regimens applied to the two groups selected for the stimulation experiment are typical of the way these two major classes of adult poultry are managed commercially. Severe food restriction is rarely applied to layers and broiler parent stock are never fed ad libitum. The lack of effect of restricted rearing on layers compared with that on broiler parents is clearly demonstrated by the data on egg production. To our knowledge the effects of restricted feeding during rearing on subsequent egg production in layer and broiler lines in the same experiment has not previously been reported. Lee et al. (1971) showed that restricting food produced variable results on the rate of lay in layers, with a small average improvement in the rate of lay in restricted birds. Food restriction delayed the onset of lay more in broiler parent than in layer stock, but this was probably a consequence of the application of continued restriction in the former. Food restriction was continued in the broiler parent stock to control the incidence of multiple ovulation as the birds came into lay (Hocking et al., 1989). Of the 32 broiler females in this experiment, 22 had at least one pair of follicles of similar size (less than $\mathrm{I} g$ difference compared with at least $3 \mathrm{~g}$ between follicles recruited on different days), whereas there were none in the layers. The prevalence of multiple recruitment of follicles to the yellow hierarchy is still greater in broiler breeders fed ad libitum (Hocking et al., 1987) and the effect on egg production and the incidence of soft-shelled and cracked eggs is clearly seen.

The greater activity of ornithine decarboxylase in small white follicles (5-6 mm diameter) from PMSG-stimulated broiler parent stock compared with that in follicles of similar size from laying hens is consistent with the hypothesis that follicular tissue at this stage of growth is more sensitive to stimulation by endogenous pituitary gonadotrophins in broilers than it is in layers. The two sizes of small white follicle were chosen because follicles of $\mathbf{2}-\mathbf{3} \mathrm{mm}$ diameter are considered to be growing and there is little atresia compared with follicles of 5-6 mm diameter (Gilbert et al., 1983). Furthermore, in follicles of $6 \mathrm{~mm}$ diameter, there are physiological changes that are consistent with the suggestion that selection to the hierarchy occurs at this stage (Robinson and Etches, 1986; Tilly et al., 1991, 1992). Armstrong (1994) reported greater ornithine decarboxylase activity in follicles of $1-3 \mathrm{~mm}$ diameter compared with follicles of 3-6 mm diameter in agreement with these results. Greater sensitivity to stimulation in 5-6 mm follicles could be related to the recruitment of more than one follicle to the hierarchy of large yellow follicles, a characteristic feature of broiler parents (Hocking et al., 1987) and a major cause of the relatively poor egg production of broiler lines.

The increase in ovulation rate in response to selection for growth in avian species is well established. The evidence is from comparisons of large and small commercial lines (Hocking, 1990, 1992), selection experiments for growth (Reddy and Siegel, 1977; Nestor and Bacon, 1972) or multiple ovulation (Abplanalp et al., 1977), and from work on the effect 
of the dwarfing gene $(d w)$ on body size and the number of ovarian follicles (Abplanalp et al., 1987).

The interaction of growth factors, particularly insulin-like growth factor I (IGF-I) and FSH on growth and development of ovarian tissue in mammals has been reported (Giudice, 1992). If selection for growth rate has favoured genes for growth factors or their receptors, which are active or transcribed in the ovary, and these interact to modify the effect of pituitary hormones, increased recruitment of follicles could result. There is some evidence for an effect of growth factors on ovarian folliculogenesis in follicles of $6-8 \mathrm{~mm}$ diameter in poultry. $\mathrm{Li}$ and Johnson (1993a, b) reported an inhibitory role for transforming growth factor $\alpha$ and epidermal growth factor and no effect for IGF-I on FSH-stimulated enzyme activity and steroid production in $6-8 \mathrm{~mm}$ follicles. D. G. Armstrong and C. O. Hogg (personal communication) found a unique mRNA band for IGF-II in follicles of $4-6 \mathrm{~mm}$ diameter; this band is absent from yellow follicles and only weakly present in follicles of $2-4 \mathrm{~mm}$ diameter. A role for several growth factors in modulating growth and steroid function in thecal and granulosa cells from hierarchical follicles has been reported (Onagbesan et al., 1994; Peddie et al., 1994; Roberts et al., 1994), further strengthening the view that changes in growth factors and their receptors may underlie the increased sensitivity to stimulation by gonadotrophins of follicles of $5-6 \mathrm{~mm}$ diameter from broiler parent females.

The response to PMSG with time suggests that ornithine decarboxylase activity could be assessed between $1 \mathrm{~h}$ and $3 \mathrm{~h}$ after its injection. There was a small peak in the difference between control and PMSG-stimulated ornithine decarboxylase activity $I \mathrm{~h}$ after injection in contrast to earlier data which showed maximum activity $3 \mathrm{~h}$ after injection of $250 \mathrm{mg}$ ovine LH (Armstrong, 1986b). This study was based on incubation in vilro of granulosa cells from the largest preovulatory follicle, in contrast to the stimulation in vivo of thecal cells in the present work. Preparations of cells described here do not contain contaminating granulosa cells (Armstrong, 1986a). An increase in the protein content of the follicles from PMSG-stimulated birds was unexpected and may indicate that the sustained increase in ornithine decarboxylase activity is partly an effect of PMSG on protein synthesis. Almost all birds in this experiment had an egg in the shell gland or isthmus; therefore, the stage of the follicular cycle was similar in most of the birds.

In conclusion, it has been shown that, compared with layer stock, ovarian tissue from broiler parent females is more sensitive to gonadotrophin stimulation at the stage when small follicles are recruited into the hierarchy of the yellow follicles that survive to ovulation. It is proposed that growth factors or their receptors or both, that have been altered by selection, interact with gonadotrophins and result in the observed increased rate of ovulation and poor egg production of birds selected for high growth rate.

The broiler chicks were donated by Ross Breeders Ltd, Newbridge, Midlothian. We are grateful for the assistance of $\mathrm{R}$. Bernard and for helpful discussions with D. G. Armstrong, who also provided the difluoromethylornithine which was originally a gift from Merrill Dow Research Institute, Strasbourg. The research was funded by MAFF.

\section{References}

Abplanalp H, Lowry DC and van Middelkoop JH (1977) Selection for increased incidence of double-yolked egg in White Leghorn chickens British Poultry Science 18 585-595

Abplanalp H, Napolitano D and Tai C (1987) The effects of the gene for sex-linked dwarfing (dw) on egg production and body composition of hens of a line selected for high numbers of multiple yolked eggs journal of Animal Breeding and Genetics 104 304-308

Armstrong DG (1986a) Changes in ornithine decarboxylase activity in ovarian follicles of the laying hen (Gallus domesticus) during the ovulatory cycle Journal of Endocrinology 110 211-216

Armstrong DG (1986b) Omithine decarboxylase activity in granulosa tissue from the laying hen (Gallus domesticus) during stimulation with ovine lutropin in vitro IRCS Medical Science 14 27-28

Armstrong DG (1987) Ornithine decarboxylase activity in small ovarian follicles of the laying hen (Gallus domesticus). A comparison of follicles from several regions of the ovary Journal of Endocrinology 112 183-187

Armstrong DG (1994) The effect of LH, FSH and pregnant mares' serum gonadotrophin on ornithine decarboxylase activity in thecal and granulosa tissue during follicular growth and atresia in laying hens (Gallus domesticus) Journal of Reproduction and Fertility 100 273-278

Auvinen, Paasinen A, Andersson LC and Höta E (1992) Ornithine decarboxylase activity is critical for cell transformation Nature $\mathbf{3 6 0} 355-358$

Bradford MM (1976) A rapid and sensitive method for the quantitation of microgram quantities of protein utilising the principle of protein-dye binding Analytical Chemistry 72 248-254

Etches RJ (1990) The ovulatory cycle of the hen Crifical Reviews in Poultry Biology 2 293-318

Gilbert AB, Perry MM, Waddington D and Hardie MA (1983) The induction of atresia in establishing the follicular hierarchy in the ovary of the domestic hen (Gallus domesticus) Journal of Reproduction and Fertility $69221-227$

Giudice LC (1992) Insulin-like growth factors and ovarian follicular development Endocrine Reviews 1364 I-669

Hocking PM (1990) Comparison of the effects of the degree of food restriction during rearing on ovarian function at the onset of lay in unselected ducks (Anas platyrhynchos) and in a line selected for improved feed efficiency British Poultry Science 31 351-359

Hocking PM (1992) Genetic and environmental control of ovarian function in turkeys at sexual maturity Brifish Poultry Science 33 437-448

Hocking PM (1993) Effects of body weight at sexual maturity and the degree and age of restriction during rearing on the ovarian follicular hierarchy of broiler breeder females British Poultry Science 34 793-801

Hocking PM, Waddington D, Walker MA and Gilbert AB (1987) Ovarian follicular structure of White Leghorns fed ad libitum and dwarf and normal broiler breeders fed ad libitum or restricted to point of lay British Poultry Science 28 493-506

Hocking PM, Waddington D, Walker MA and Gilbert AB (1989) Control of the development of the ovarian follicular hierarchy in broiler breeder pullets by food restriction during rearing British Poultry Science 30 161-174

Johnson PA, Palmer SS and Bahr JM (1985) Hormone-stimulable adenylyl cyclase and steroid concentration of follicles of the pregnant mares' serum gonadotropin-treated hen Biology of Reproduction 32 828-833

Katanbaf MN, Dunnington EA and Siegel PB (1989) Restricted feeding in early and late feathering chickens. 2. Reproductive responses Poultry Science $\mathbf{6 8}$ $352-358$

Lee PJW, Gulliver AL and Morris TR (1971) A quantitative analysis of the literature concerning the restricted feeding of growing pullets. British Poultry Science 12 413-437

Li $Z$ and Johnson AL (1993a) Regulation of $\mathrm{P}_{450}$ cholesterol side-chain cleavage messenger ribonucleic acid expression and progesterone production in hen granulosa cells Biology of Reproduction 49 463-469

Li $\mathrm{Z}$ and Johnson AL (1993b) Expression and regulation of cytochrome $\mathrm{P}_{450}$ $17 a$-hydroxylase messenger ribonucleic acid levels and androstenedione production in hen granulosa cells Biology of Reproduction 49 1293-1302

Metcalf BW, Beg P, Danzin L, Jung MJ, Casara P and Vevert JP (1978) Catalytic irreversible inhibition of mammalian ornithine decarboxylase (EC 4.1.1.17) by substrate and product analogues Journal of the American Chemical Society $1002551-2553$

National Algorithms Group (1993) GENSTAT 5 Reference Manual. Clarendon Press, Oxford

Downloaded from Bioscientifica.com at 04/26/2023 09:20:07AM 
Nestor KE and Bacon W (1972) Production of defective eggs by egg- and meat-type turkey hens Poultry Science 51 1361-1365

Onagbesan OM, Peddie MJ and Williams L (1994) Regulation of cell proliferation and estrogen synthesis by ovine LH, IGF-I, and EGF in thecal interstitial cells of the domestic hen cultured in defined media General and Comparative Endocrinology 94 261-272

Peddie MJ, Onagbesan OM and Williams J (1994) Chicken granulosa cell proliferation and progesterone production in culture: effects of EGF and thecal secretions General and Comparative Endocrinology 94 341-356

Pegg AE and McCann PP (1982) Polyamine metabolism and function American Journal of Physiology 243 212-221

Reddy PRK and Siegel PB (1977) Selection for body weight at eight weeks of age. 12. Egg production in selected and relaxed lines Poultry Science $\mathbf{5 6}$ $673-686$
Roberts RD, Sharp PJ, Burt DW and Goddard C (1994) Insulin-like growth factor- 1 in the ovary of the laying hen: gene expression and biological actions on granulosa and thecal cells General and Comparative Endocrinology $93327-336$

Robinson FE and Etches RJ (1986) Ovarian steroidogenesis during follicular maturation in the domestic fowl (Gallus domesticus) Biology of Reproduction $\mathbf{3 5}$ 1096-1105

Tilly JL, Kowalski KI and Johnson AL (1991) Stage of follicular development associated with the initiation of steroidogenic competence in avian granulosa cells Biology of Reproduction 44 305-314

Tilly JL, Kowalski KI, Li Z, Levorse JM and Johnson AL (1992) Plasminogen activator and thymidine incorporation in avian granulosa cells during follicular development and the periovulatory period Biology of Reproduction 46 195-200 